\title{
DIFFERENTIATION OF CRIMINAL LIABILITY OF MEDICAL PROFESSIONALS
}

D0I: 10.36740/WLek202012205

\author{
Natalia Antoniuk \\ SUPREME COURT, KYIV, UKRAINE
}

\begin{abstract}
The aim: Determining the need to differentiate the criminal liability of medical workers for damage caused in the course of professional activity.

Materials and methods: This following research is based on an analysis of laws (21 laws), court judgments and case files (108 judgments and 8 case files), judgments of the European Court of Human Rights (4) and the legal doctrine of criminal law. Comparative, systematic, analytic, and empiric methods have been used in this research. During the preparation of this article the results of personal experience of the scientific work (17 years), the experience of advocacy (11 years), and the experience of the Supreme Court's judge have been applied.

Results: The analysis of case files, thoughts of scientists and lawyers-practitioners allowed to propose criteria and indicators influencing increasing or decreasing of social dangerousness of actions committed by medical professionals. It is noted that the necessity of the legislator to consider the close interrelation of professional medical services and influence on the health of persons who demand medical services or need health care during differentiation of criminal liability.

Conclusions: The necessity of differentiating approach to the criminal liability of medical professionals who inflict health damages or death is stated in comparison with the liability of general subjects of a crime.
\end{abstract}

KEY WORDS: a differentiation of criminal liability, a medical worker, a criminal offense

Wiad Lek. 2020;73(12 p. II):2728-2732

\section{INTRODUCTION}

Criminal liability for death or bodily injuries cannot be equal. Such damages can have caused by various forms of guilt (intent or negligence), by different aims (vengeance, obtaining profits), under different circumstances (during medical services, as a result of the conflict), to different victims (old people, minors), by different subjects (general or special), etc. Such damage may be caused by persons who are closely related to the provision of professional medical services.

Obviously, the professional activity of medical professionals is engaged with influence upon the health of those who demand medical services or who need health care. That's why there is an increased risk of inflicting health damages or death. Considering this fact, the question arises if it is necessary to differentiate criminal liability between medical professionals and general subjects of crime inflicting the same pecuniary or physical damages.

\section{THE AIM}

This research aims to ground the necessity of medical professionals criminal liability differentiation for damages inflicted while performing their professional duties. First of all, the answer is to be found whether in any case of causing damages (pecuniary or physical) medical professionals must bear criminal liability.

\section{MATERIALS AND METHODS}

This research is based on philosophical, comparative, analytic, systematic, empiric, and other methods, methods of formal logic, and methods of interpretation. The empiric basement of this research consists of case files (8 case files, which have been the subject of Supreme Court consideration, as well as separate opinions of judges concerning results of these criminal proceedings), 108 trial courts and courts of appeal judgments, conclusions of the Department of Analytical and Legal Work of Supreme Court considering the subject of the analyzed issue, judicial statistics for the period of 2018-2019 provided by the State Judicial Administration of Ukraine, a summary of the judicial practice, made by the Law Department of the Supreme Court, judgments of the European Court of Human Rights (4 judgments). Documents of medical associations (of the USA and Australia) and criminal codes of certain states (Ukraine, Poland, Latvia, and Slovenia) have been analyzed too.

Personal experience of work as a judge has been applied. For instance, the author of the article was the reporting judge during criminal proceedings concerning the accusation of the medical professional whose misconduct caused the death of a minor (case file no. 439/397/17) [1]. This proceeding became the subject of consideration by the Grand Chamber of the Supreme Court, because of the 
exclusive legal problem of the possibility of exemption of a medical professional from criminal liability.

\section{RESULTS}

Analysis of case files, thoughts of scientists and practical workers allowed to propose criteria and indicators influencing increasing or decreasing of social dangerousness of actions committed by medical professionals. This is said about the necessity of the legislator to consider the close interrelation of professional medical services and influence on the health of persons who demand medical services or need health care during differentiation of criminal liability.

To achieve the principle of justice, the legislator shall differentiate the criminal liability of medical professionals for damages inflicted while performing their professional duties. This is necessary to take into account the permanent risk of damaging health or depriving the life of the patient. At the same time, this is important to consider the special education of a medical professional and his voluntary choice of obligations to provide health care and medical services.

Special grounds or requirements for exemption from criminal liability considering such a feature of special subject of crime as a medical professional shouldn't be provided. These provisions of the general part of criminal law shall be universal without any dependence on special features of the subject of crime.

We suppose that the criminal liability of medical professionals for inflicting intentional physical damage shall be envisaged by general legal norms. At the same time, medical professional who has caused this damage at the patient's demand, shall bear the liability differentiated decreasingly (by prescribing privileged norm).

Criminal liability for negligence causing damages shall be imposed by special norms. Permanent risk of inflicting damage to patients due to the specificity of the professional duties of medical professionals must be taken into account by decreasing the lower limits of sanctions in comparison with sanctions of general norms envisaging criminal liability of the general subject.

At the same time, the criminal liability of a medical professional who has caused physical damage to his patient during the official working time and in a state of alcoholic or drug intoxication shall be differentiated increasingly.

A medical professional cannot be a subject to criminal liability for pecuniary damages. Such damages may be compensated according to civil procedures.

\section{DISCUSSION}

The primary role of the differentiation of criminal liability is achieving justice. So, differentiating criminal liability according to the criteria of a character or level of social dangerousness, personal characteristics of guilty one must result in prescribing in the law the borders for providing forms of criminal liability.

Legislators of different states use various means of differentiation of criminal liability. We will not define all the volume of means of criminal liability differentiation. Nevertheless, we will highlight the ones which are connected with the subject of this research. It is said about the exemption from criminal liability, qualified and privileged features of bodies of crime, prescribing special bodies of crime, defining borders of punishment. These means will be analyzed only in part, concerning committing criminal actions by the medical professional.

This is worth to be mentioned, that in some states, the criminal liability of medical professionals is envisaged by general legal norms (Poland, Slovenia). In the other - legislator prescribes special norms (Ukraine, Latvia). Scientists pay much attention to studying of the legislative approaches to the differentiation of medical professionals criminal liability in the criminal laws of different states. They indicate grounds taken into consideration by national legislators in this process as well $[2,3,4]$.

Usually, this is said that medical professionals shall bear stricter level of liability, than the other people who inflicted damage to health or death. However, we suppose that suggestions on increasing strictness of the criminal liability of a medical professional must be made only after considering how often he is at risk of inflicting damage to his patient's health. Regular professional activity of medical professionals is closely connected with providing health care to those who need them or medical services to those who demand.

Peculiarities of professional activities of medical professionals and permanent risk of inflicting damage to health or death of the patient were a separate aspect of research of the exemption from criminal liability problem concerning reconciliation with the victim of crime (case file no. 439/397/17) [1] . In this case, the doctor-anesthesiologist of the anesthesiology and resuscitation department of one of the local hospitals has been charged in inadequate fulfillment of professional duties, negligent medical manipulation (puncture of left collarbone vein by injection needle for mounting catheter). This medical manipulation has been performed contrary to the common technique of catheterization of collarbone vessels. Such action has caused the death of the minor.

102 court judgments have been analyzed while working over the mentioned criminal proceeding [5]. This analysis gives reason to state that in $94 \%$ of proceedings, courts have delivered judgments concerning exemption from criminal liability of doctor due to the reconciliation with the family of the deceased patient. Only 7 proceedings are resulting in rejection of the application of a guilty person for exemption from criminal liability. These rejections have been motivated by the impossibility of reconciliation because of the irreversibility of consequences in the form of death, which cannot be compensated to the deceased.

That's why a situation in practice of criminal law application has occurred resulting in the possibility of exemption from criminal liability due to reconciliation with the family of the deceased by most of the medical professionals who have caused negligently death to their patients.

The Grand Chamber of the Supreme Court has stated that the right of reconciliation is personal; it cannot be acquired by another person or delegated to anyone. If death is caused 
as the result of a crime (medical as well) then nobody can (even relatives) express the will of the victim for reconciliation with the accused. That's why in such case exemption from criminal liability due to reconciliation is impossible.

It should be stressed that all 16 judges in this proceeding have supported such an approach; there have been no separate opinions or objecting points of view. The mentioned approach has been generally supported by members of the Scientific and Advisory Board of the Supreme Court, who have given their scientific conclusions concerning the exclusive legal problem in this case.

From the stated above it is obvious that it is inappropriate to differentiate grounds and requirements of an exemption from criminal liability basing on the feature of committing a crime by the medical professional. Grounds and requirements of an exemption from criminal liability are to be universal for all subjects of crime.

Prescribing qualified or privileged features, formulation of special bodies of crime, defining borders of punishment are the following means of the differentiation of criminal liability. Criteria decreasing or increasing social dangerousness of crime committed by a medical professional while performing his professional duties shall not be omitted by the legislator. Taking into account the fact that damages inflicted as the result of performing professional duties by medical professionals are widespread it is justified to highlight the necessity to define criteria that provide support for complex differentiation of criminal liability, though this question concerns world medical practice globally.

A medical professional is in the state of permanent risk of causing damage. The essence of the medical profession is tightly interrelated with the necessity to evaluate the state of health of the patient and to provide health care he certainly needs. Traditionally medical professionals use clinic protocol - a framework of medical treatment, which must be applied in any certain clinic situation. However, peculiarities of the human body of a patient, existing illnesses, etc. cause undoubted influence on the general view on medical treatment of any patient. These aspects are sometimes not evident and are not considered by the doctor. By the way, mistakes resulting from the peculiarities of the patient and his body may occur during medical treatment as well as during any other professional activity. As researchers state, each doctor does his/her duties in the wrong way at least once in his/her career [6]. Moreover, following data provided by the World Health Organization, medical mistakes occur in quantity from 8 to $12 \%$ of all situations of hospitalization in the states of the European Union [7]. Types of medical mistakes as well as questions of the feasibility of medical professionals' criminal liability are researched by specialists in criminal and medical law $[8,9,10]$.

Positive influence on the state of a patient's health is the aim of a medical professional. However, sometimes such positive influence doesn't occur. Or even worse - the state of the patient's health deteriorates, death or bodily injuries happen.

Researching the problem of criminal liability of medical professionals R. Ferner suggests that a medical professional shall bear criminal liability for intentional damage or damage inflicted in the state of inebriation or drug intoxication [11].

Damage by medical professional acting with direct intent can be caused in two situations. First - inflicting damage on patient's demand (for instance euthanasia) or - deliberate damaging the patient's health acting with personal motives (vengeance, mercenary motive, etc.)

In the first of the mentioned situations, when the patient himself asks about inflicting damage to health even causing death motivated by strong pain as the result of illness, incurable illness, we suppose that there are grounds for decreasing the level of criminal liability of a medical professional. The European Court of $\mathrm{Hu}-$ man Rights in the case of Pretty v. the United Kingdom (Application no. 2346/02) [12] has stated, that the right to be deprived of life by a third person cannot be interpreted using Article 2 of the Convention. However, in the case concerning the right to access medicine, able to cause the death of the applicant (who has a mental illness), the European Court of Human Rights noted, that state authorities shall obstruct a person to deprive herself life if this decision is not conscious and willful. (Case of Haas v. Switzerland (Application no. 31322/07)). We suggest that the intensity of criminal influence on a guilty person must be substantially decreased if death has been caused by the demand of a patient.

If deliberate inflicting health damages or death are made under the influence of "dirty" motives - the strictness of criminal liability of a medical professional must increase, taking into account that the patient addressed for medical service, but instead received injury. At the same time, such situations are quite rare. That is why strictness of criminal liability can be increased by a court in the process of individualization of criminal liability. Prescribing mentioned aggravating circumstances in the criminal law act is unjustified considering their exclusiveness.

Thus, criminal liability for deliberate causing patient's death or bodily injury by medical professional shall be differentiated only when it is inflicted on patient's demand (by decreasing strictness). When this damage is inflicted under the influence of other motives, then increase of the intensity of means of criminal legal impact can be provided at the stage of imposing punishment by a court (in the process of individualization of criminal liability), without prescribing such an increase in the criminal law act.

Criminal liability of medical professionals for negligent causation while performing professional duties death or health injury is necessary. Court's judgments demonstrate that criminal negligence during medical treatment in many cases is evident and cannot be ignored by the state.

N. Gutorova, O. Zhytniy, and T. Kahanovska aptly observe that in the states where special norms concerning medical negligence are prescribed, sanctions for committing this crime are less strict [2]. In our opinion, a legislator while defining borders of sanction consider the indicator of permanent risk of causing death or bodily injury while performing professional medical treatment. We consider such an approach as justified. Moreover, at the stage of 
individualization of criminal liability courts often impose punishments which are not associated with imprisonment.

Such an example is described in the case file no. 447/781/16-к. the doctor has finished with the delivery of a baby, but after a while noticed the woman is bleeding. According to the forensic medical examination conclusion, the doctor has breached the demands of clinic protocols "Obstetric bleeding" and "Hemorrhaging shock"; undiagnosed partial uterus rupture, underestimation of blood loss and total state of the woman in labor, untimely calling anesthesiologist, untimely informing hospital administration and department caused aggrieved hemorrhaging shock, irreversible changes in main parts of the human body, late surgery and death [14]. The court has imposed punishment of 2 years of confinement but exempted guilty person from serving it due to the limitation period ending.

At the same time, analyzing the court judgment the conclusion can be made that there is sufficient difference in social dangerousness between situations when a medical professional acts diligently, use all the possible means to achieve a positive influence on the human body but fails or when a medical professional provides medical treatment in the state of inebriation or leaves the patient without necessary treatment at all.

Damage inflicted by a medical professional in the state of inebriation or drug intoxication must aggravate his liability when this state occurred while working and while being obliged to perform health care or medical services.

Patients' treatment, medical manipulations (as well as surgeries), performing the other professional functions by a medic in the state of inebriation or drug intoxication is an indicator influencing the level of social dangerousness of the committed. The fact of the subject's realization, that his professional activity is connected with medical treatment, so the risk of inflicting damage is high, but ignored this, is the most important factor in such cases.

A medical professional committed himself to qualified medical treatment, provided in time. This approach is recognized worldwide, which can be seen in different legal acts and ethical codes. For instance, article 1.1.6 of the Code of Medical Ethics of AMA (American Medical Association) provides that physicians individually and collectively share the obligation to ensure that the care patients receive is safe, effective, patient centered, timely, efficient, and equitable [15]. This aspect is similarly regulated by the Medical Board of Australia in article 1.4 of A Code of Conduct for Doctors in Australia. Provisions of the mentioned Code state that doctors must make the care of patients their first concern and to practice medicine safely and effectively [16]. In Bases of the legislation of Ukraine on health care declare obligations of the doctor to perform timely and qualified diagnosis and treatment of a patient (part 2 of article 34) [17].

That is why while performing his duties a medical professional must be in such a state that allows him to provide timely and qualified health care. Being in the state of inebriation or drug intoxication while performing professional duties and inflicting deadly bodily injuries of the patient must increase the strictness of the medical professional's criminal liability. Since actions leading to a state of intoxication are accompanied by an understanding of the necessity of performing health care or medical services.

We suggest legislator to differentiate criminal liability of medical professional who caused patients death or health damages directly in the provisions of the Criminal code.

Character and volume of socially dangerous consequences is an indicator that reflect increasing social dangerousness of crime, committed by a medical professional. The legislator usually differentiates criminal liability for consequences in the form of bodily injuries of a certain level of severity or the form of death. Minimal damage resulting in criminal liability of medical professional shall be equal with the level of severity of bodily injury resulting in criminal liability of general subject. Tarasevych T. in her $\mathrm{PhD}$ thesis makes similar conclusions. She suggests that consequences shall be directly named in the dispositions of certain articles of the Criminal code instead of the term "heavy consequences" [18].

Taking into consideration that medical professionals provide medical treatment or services, they shall only be incriminated for consequences of death or bodily injury. Inflicting pecuniary damages is indirectly related to the duties of a medical professional and legal relation concerning these duties. That is why we suggest that such damage must be compensated in civil procedure. It is properly said in the literature that criminal intervention considering the damage caused by a medical professional is appropriate when it is really necessary due to the lack of other effective legal mechanisms [19]. There are a lot of examples in court judgments of compensations for pecuniary or non-pecuniary damages inflicted as the result of improper medical treatment or service. For instance, the Supreme Court judged (case file no. 537/4429/15-ц) the hospital to pay non-pecuniary damage for violations during delivery of a baby [20].

In this article, we have analyzed part of the differentiation means of medical professionals' criminal liability. At the same time, it is necessary to research the feasibility of envisaging features influencing the criminal liability of a medical professional in the Criminal Code, such as the age of the victim, the psychological and emotional state of a medical professional during performing medical treatment, a multiplicity of crimes (as well of negligent ones), qualification of the doctor, features of victim's state (state of emergency, life-endangering state, etc.) These questions will be the subject of further studies concerning the differentiation of medical professionals' criminal liability for inflicting damage while performing their professional duties.

\section{CONCLUSIONS}

Considering the peculiarities of the medical profession, the permanent influence of treatment and services of medical professionals on such values as life and health, we suggest that there are grounds for differentiation of medical professionals' criminal liability for damages caused 
while performing their professional duties. The necessity to differentiate criminal liability of medical professionals alongside general subjects of crime is motivated by such features of the first group of subjects as special education, professional duty and permanent risk to inflict death or health damages. The first two features increase the level of social dangerousness, the last one - decreases. Acting in a state of inebriation or drug intoxication, deliberate causing physical damage on patient's demand are the indicators influencing the level of social dangerousness of a medical professional. Such a differentiating approach helps the legislator to set justified borders of criminal law act application and to provide clear limits for the individualization of criminal liability by a court.

\section{REFERENCES}

1. Postanova Velykoi Palaty Verkhovnoho Sudu [Resolution of the Grand Chamber of the Supreme Court] vid 16 sichnia 2019 roku (Sprava № 439/397/17, provadzhennia № 13-66ks18). Available from: http:// reyestr.court.gov.ua/Review/79298600 [reviewed 2020.08.24] (Ua).

2. Gutorova N, Zhytnyi 0, Kahanovska T. Medical negligence subject to criminal law. Wiadomości Lekarskie. 2019, tom LXXII, nr 11 cz. I: 21612166 doi: 10.36740/WLek201911118.

3. Šepec M.: Medical Error - Should it be a Criminal Offence? MEDICINE, LAW \& SOCIETY. April 2018, 11;1:47-66 Available from: file://C:/Users/ Surface\%20PC/Downloads/92-Article\%20Text-279-1-10-20180425. pdf [reviewed 2020.08.24].

4. Lykhova S., Ustynova I., Husar 0. Et al. Topical Issues of Criminal Liability of Medical or Pharmaceutical Workers under the Criminal Code of Ukraine (Article 140 of the Criminal Code of Ukraine) International Journal of Recent Technology and Engineering (IJRTE), 8;4S:87-92 Available from: https://www.jjte.org/wp-content/uploads/papers/ v8i4S/D10281184S19.pdf [reviewed 2020.08.24].

5. Ukhvala Kasatsiinoho kryminalnoho sudu vid 24 zhovtnia 2018 roku [Ruling of the Criminal Court of Cassation] (Sprava № 439/397/17, provadzhennia № 51-657km17) Available from: http://reyestr.court. gov.ua/Review/77910899 [reviewed 2020.08.24] (Ua).

6. Munjae Lee. The Effects of Criminal Punishment on Medical Practices in the Medical Environment Int. J. Environ. Res. Public Health 2019, 16(4), 604; doi.org/10.3390/ijerph16040604.

7. World Health Organization regional office for Europe data and statistics. Available from: https://www.euro.who.int/en/health-topics/Healthsystems/patient-safety/data-and-statistics [reviewed 2020.08.24].

8. Liang B. A A system of medical error disclosure. Quality \& Safety in Health Care. 2002;1:64-68. Available from: https://www.ncbi.nIm. nih.gov/pmc/articles/PMC1743574/ [reviewed 2020.08.24].

9. Grober E.D Defining medical error. Canadian Journal of Surgery. 2005;48(1):39-44, Available from: https://www.ncbi.nlm.nih.gov/ pmc/articles/PMC3211566/ [reviewed 2020.08.24].

10. Senyuta I. YA Defekty nadannya medychnoyi dopomohy: ponyattya i vydy [Defects in health care delivery: concepts and types]. Medychne pravo. 2017;1(19):55-66. (Ua).

11. Ferner RE: Medication errors that have led to manslaughter charges. BMJ 2000;321(7270):1212-1216, Available from: https://www.ncbi. nlm.nih.gov/pmc/articles/PMC1118964/ [reviewed 2020.08.24].

12. Case of Pretty v. The United Kingdom (application no. 2346/02), Available from: https://hudoc.echr.coe.int/fre\# $\{\% 22$ item id\%22:[\%22001-60448\%22]\} [reviewed 2020.08.24].
13. Case of Haas v. Switzerland] (application no. 31322/07). Available from: file:///C:/Users/Surface\%20PC/Downloads/CASE\%200F\%20HAAS\%20 v.\%20SWITZERLAND\%20-\%20[Russian\%20Translation]\%20by $\% 20$ the\%20Moscow\%20Lawyers'\%20Club.pdf [reviewed 2020.08.24].

14. Postanova Kasatsiinoho kryminalnoho sudu [Resolution of the Criminal Court of Cassation] vid 12 liutoho 2019 roku (sprava № 447/781/16-k, provadzhennia 51-690 km 18). Available from: http://reyestr.court.gov. ua/Review/79846854 [reviewed 2020.08.24] (Ua).

15. AMA Code of Medical Ethics. Available from: https://www.ama-assn. org/delivering-care/ethics/quality [reviewed 2020.08.24].

16. A Code of Conduct for Doctors in Australia. Available from: https://www.medicalboard.gov.au/documents/default.aspx?r ecord $=$ WD10\%2F1277\&dbid=AP\&chksum $=$ eNjZ0Z\%2FajN70xjv HXDRQnQ\%3D\%3D [reviewed 2020.08.24].

17. Zakon Ukrainy Osnovy zakonodavstva Ukrainy pro okhoronu zdorov'ia [Law of Ukraine On Basis of the Legislation of Health Care] vid 19.11.1992, Available from: https://zakon.rada.gov.ua/laws/ show/2801-12\#Text [reviewed 2020.08.24] (Ua).

18. Tarasevych T. Medychnyi pratsivnyk yak spetsialnyi subiekt zlochynu [Medical professional as the special subject of crime] Ph. D. thesis abstract. Kyiv, 2011 (Ua).

19. Vallejo-Jiménez, Geovana A.; Nanclares-Márquez, Juliana. Legal review of the civil, criminal, and administrative consequences of informed consent violation in medical practice. Colombian Journal of Anesthesiology. April-June 2019, 47;2:107-112. doi: 10.1097/ CJ9.0000000000000102.

20. Postanova Kasatsiynoho tsyvil'noho sudu u skladi Verkhovnoho Sudu [Judgment of Civil Cassation Court in Supreme Court] 14.03.2018 u spravi № 537/4429/15-ц. Available from: http://www.reyestr.court. gov.ua/Review/72909007 [reviewed 2020.08.24] (Ua).

Academic research. Part of Doctoral research of differentiation of criminal liability in Ukraine.

\section{ORCID and contributionship:}

Natalia Antoniuk ORCID: 0000-0002-7582-2071 ${ }^{A, B, C, D, E, F}$

\section{Conflict of interest:}

The Author declare no conflict of interest.

\section{CORRESPONDING AUTHOR} Natalia Antoniuk

Supreme Court, Kyiv, Pylypa Orlyka street 8, tel: +380679665233, e-mail:antoniuk_natalia@ukr.net

Received: 25.08 .2020

Accepted: 27.11 .2020

A - Work concept and design, B - Data collection and analysis, C - Responsibility for statistical analysis, D-Writing the article, $\mathbf{E}$-Critical review, $\mathbf{F}$ - Final approval of the article 